\title{
Afrojoyeuxia gen. n. and Hunkeleriella gen. n., two new genera of cestodes (Cyclophyllidea: Anoplocephalidae) from African rodents
}

\author{
Voitto Haukisalmi
}

Finnish Museum of Natural History LUOMUS, University of Helsinki, Finland

\begin{abstract}
Based on the study of type material, two new genera of cestodes (Cyclophyllidea: Anoplocephalidae) are proposed for Paranoplocephala Lühe, 1910 sensu lato species from African rodents. Afrojoyeuxia gen. n., proposed for A. gundii (Joyeux, 1923) comb. n. from Ctenodactylus gundi (Rothmann) (Hystricomorpha: Ctenodactylidae), is characterized by a high length/width ratio of mature proglottids, longitudinally extensive testicular field positioned anterior to the female glands, an ovoid or subspherical cirrussac and a thick, conical cirrus. Hunkeleriella gen. n., proposed for H. dasymidis (Hunkeler, 1972) comb. n. from Dasymys incomtus (Sundevall) (Myomorpha: Muridae), differs from related genera mainly by its short (10-20 mm) and wide strobila and neck, unilateral genital pores (exceptionally with a few changes per strobila), the position of the genital pores (slightly anterior to the middle of proglottid margin) and initially tube-like early uterus (later reticulated). Parandrya Gulyaev et Chechulin, 1996, earlier suggested to be a junior synonym of Paranoplocephala, is considered to be a valid, independent genus. Evidence of non-monophyly and need for a taxonomic revision of Paranoplocephala sensu lato, as well as the phylogenetic position of $A$. gundii and H. dasymidis are discussed.
\end{abstract}

Keywords: Cestoda, Paranoplocephala, systematics, taxonomy, Ctenodactylus, Dasymys, Ethiopian region

Paranoplocephala Lühe, 1910 sensu lato (s.1.) (Cyclophyllidea: Anoplocephalidae) comprises a relatively diverse assemblage of cestodes ( $c a .35$ valid species) parasitizing mainly arvicoline rodents, i.e. voles and lemmings (Myomorpha: Cricetidae), in the Holarctic region (Tenora et al. 1986, Haukisalmi et al. 2002). Two species, i.e. Paranoplocephala primordialis (Douthitt, 1915) and Paranoplocephala sciuri (Rausch, 1947), appear, however, to be host-specific parasites of sciurid rodents (squirrels and flying squirrels, respectively), and one, Paranoplocephala longivaginata Chechulin et Gulyaev, 1998 from Myodes rutilus (Pallas), has been found sporadically also in squirrels (Douthitt 1915, Rausch 1947, Chechulin and Gulyaev 1998, Haukisalmi and Henttonen 2007, Haukisalmi and Rausch 2007). In addition, two species referable to Paranoplocephala s.1., i.e. P. gundii (Joyeux, 1923 ) and $P$. dasymidis Hunkeler, 1972, parasitise ctenodactylid (Hystricomorpha) and murid (Myomorpha) rodents, respectively, in Africa.

The allocation of species to Paranoplocephala and Andrya Railliet, 1893 has been controversial, but the morphological criteria proposed by Haukisalmi and Wickström (2005), based on the transverse and dorsoventral position of the early uterus with respect to the testes and longitudinal osmoregulatory canals, appear to provide a straightforward, phylogenetically supported distinction between these genera. Thus, all Paranoplocephala-like species in arvicoline and sciurid rodents are assigned to Paranoplocephala s.1., because their reticulated early uterus is ventral to the testes and extends bilaterally (and ventrally) across the longitudinal canals. Andrya is confined to the type species $A$. rhopalocephala (Riehm, 1881) from leporids (Lagomorpha) and, possibly, to A. octodonensis (Babero et Cattan, 1975), A. neotomae (Voge, 1946), A. boliviensis Haverkost et Gardner, 2010 and $A$. vesicula Haverkost et Gardner, 2010 from octodontid and neotomine rodents. The early reticulated uterus of Andrya is ventral to the testes, but does not extend laterally across the ventral longitudinal canals.

Several Paranoplocephala-like cestodes, including the two African species, have also been assigned to Aprostatandrya Kirshenblat, 1938. The type species of Aprostatandrya, A. macrocephala (Douthitt, 1915), is, however, morphologically and genetically closely related to $P$. omphalodes (Hermann, 1783), the type species of Paranoplocephala. Therefore, Aprostatandrya is a junior synonym of Paranoplocephala (see Rausch 1976, Haukisalmi and Henttonen 2003, Haukisalmi et al. 2004).

The position of the two African species within Paranoplocephala s.1. is intriguing because of their unusual hosts

Address for correspondence: V. Haukisalmi, Finnish Museum of Natural History LUOMUS, P.O. Box 17, FI-00014 University of Helsinki, Finland. Phone: +358 50 3185684; Fax: +358 9 19128843; E-mail: voitto.haukisalmi@helsinki.fi 
and geographical distribution. Two species from African rodents, previously placed in Anoplocephaloides Baer, 1923, have recently assigned to a new genus Afrobaeria by Haukisalmi (2008).

The present study proposes two new genera, Afrojoyeuxia gen. n. and Hunkeleriella gen. n., for Paranoplocephala gundii and Paranoplocephala dasymidis, respectively.

\section{MATERIALS AND METHODS}

The present study is based on the examination of the type material of Paranoplocephala gundii and $P$. dasymidis deposited in the Natural History Museum of Geneva (MHNG), Switzerland:

i) Paranoplocephala gundii: MHNG INVE 44562-44567 (syntypes) from Ctenodactylus gundi (Rothmann) from Gafsa, Tunisia;

ii) Paranoplocephala dasymidis: MHNG INVE 18583 (holotype) and 18584-18586 (paratypes) from Dasymys incomtus (Sundevall) from Tiegbé, Ivory Coast (collector P. Hunkeler, year of collection 1963)

\section{RESULTS}

\section{Afrojoyeuxia gen. n.}

Figs. 1-3

Diagnosis: Strobila long (up to $30 \mathrm{~cm}$ ). Scolex merging gradually with neck. Neck long and narrower than scolex when relaxed. Suckers embedded within scolex, directed laterally or anterolaterally. Proglottids craspedote, as long as or longer than wide when relaxed.

Genital pores irregularly alternating, positioned near posterior margin of mature proglottid. Testes numerous (90-100), positioned as single group anterior to female glands and terminal genital ducts. Length of testicular field at least twice length of ovary in well-relaxed proglottids; few testes placed antiporal to ovary but not reaching posterior margin of proglottid. Several testes extend lateral to longitudinal ventral osmoregulatory canals on both sides; testes do not overlap ovary.

Cirrus-sac roughly as long as vagina, very wide, almost spherical in some proglottids, overlapping or extending across ventral longitudinal canals. Everted cirrus very wide, conical, covered with minute spines. External seminal vesicle present but inconspicuous, with poorly developed layer of glandular cells.

Ovary median, usually not reaching ventral longitudinal canals. Vagina curved, posterior to cirrus-sac, covered with thick, distally widened layer of glandular cells. Seminal receptacle large; spherical or ovoid. Genital ducts pass dorsal to longitudinal osmoregulatory canals. Vitellarium slightly poral with respect to ovary. Uterus not seen in type material. Eggs with pyriform apparatus.

In ctenodactylid rodents (Ctenodactylus gundi).

Type and only species: Afrojoyeuxia gundii (Joyeux, 1923) comb. n. [syns. Andrya primordialis var. gundii Joyeux, 1923; Andrya gundii (Joyeux, 1923) Spasskii, 1951; Aprostatandrya gundii (Joyeux, 1923) Quentin, 1979;
Paranoplocephala gundii (Joyeux, 1923) Tenora, Murai et Vaucher, 1984].

E ty m o log y: The name of the new genus refers to Africa and the eminent cestodologist Charles Joyeux (1881-1966), the author of Andrya primordialis var. gundii.

Remarks. Joyeux (1923) gave a very brief account of Andrya primordialis var. gundii stating that it resembles Andrya primordialis Douthitt, 1915 (a parasite of NorthAmerican sciurids), except that the testes are more numerous and pass more extensively across the 'canals' in var. gundii. Spasskii (1951) raised var. gundii to a species level within the genus Andrya, but did not provide additional morphological data. Quentin (1979) provided a detailed redescription of $A$. gundii based on new material from the type locality, which fully confirmed the status of A. gundii as a valid species. However, Quentin (1979) assigned $A$. gundii to the genus Aprostatandrya because of the absence of a distinct 'prostatic gland'. Finally, Tenora et al. (1984) moved A. gundii to the genus Paranoplocephala, thereby following the emended diagnosis of the latter genus by Rausch (1976).

The structure of the early uterus was not visible in the type material, but according to the redescription of Quentin (1979), the early uterus is reticulate, developing into complex sacculated and fenestrated organ in pregravid proglottids, covering most of the medulla and extending ventrally across longitudinal ventral canals on both sides. If we adopt the criteria of Haukisalmi and Wickström (2005) concerning the extent and position of early uterus, A. gundii belongs to Paranoplocephala. However, A. gundii can be differentiated unambiguously from all species representing Paranoplocephala s.l. based on the shape of mature proglottids, the distribution of testes, and the shape of the cirrus-sac and cirrus.

The well-relaxed mature proglottids of $A$. gundii are as long as wide, or even longer than wide according to the illustration of Tenora et al. (1986) based on the type material. Among Paranoplocephala s.l., the relatively longest mature proglottids are found in P. arctica (Rausch, 1952) and P. fellmani Haukisalmi et Henttonen, 2001, even they do not exceed $75 \%$ and $60 \%$ of the proglottid width, respectively, when fully relaxed (Haukisalmi and Henttonen 2001, Haukisalmi et al. 2001). In most of the species of Paranoplocephala the length of the mature proglottids is less than $30 \%$ of the proglottid width.

The testicular field of $A$. gundii is very long, covering more than half of the proglottid length, and most of the testes are positioned anterior to the female glands and genital ducts. These features do not occur in other species of Paranoplocephala s.1. There are, however, species of Paranoplocephala in which some of the testes are positioned anterior to the female glands and genital ducts, but the number and longitudinal extent of these testes are low, and most of the testes are always found antiporal to the ovary. 
1

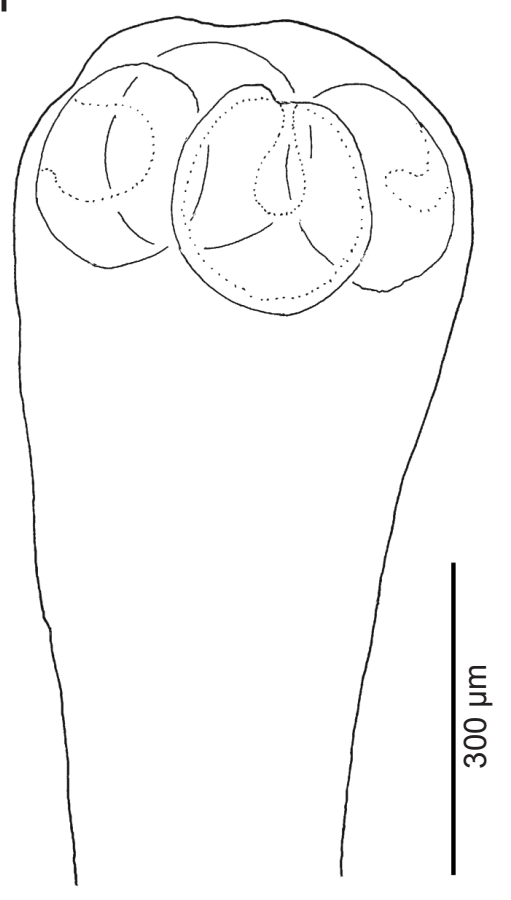

2

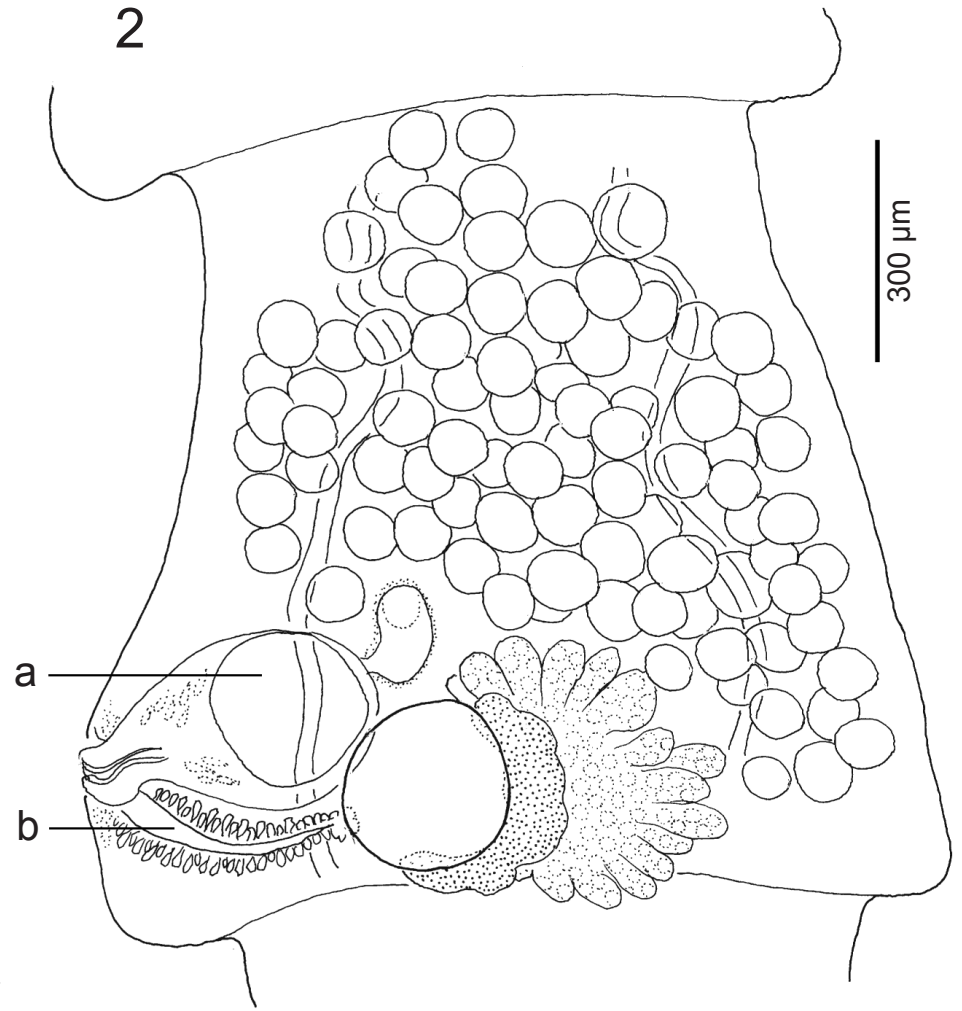

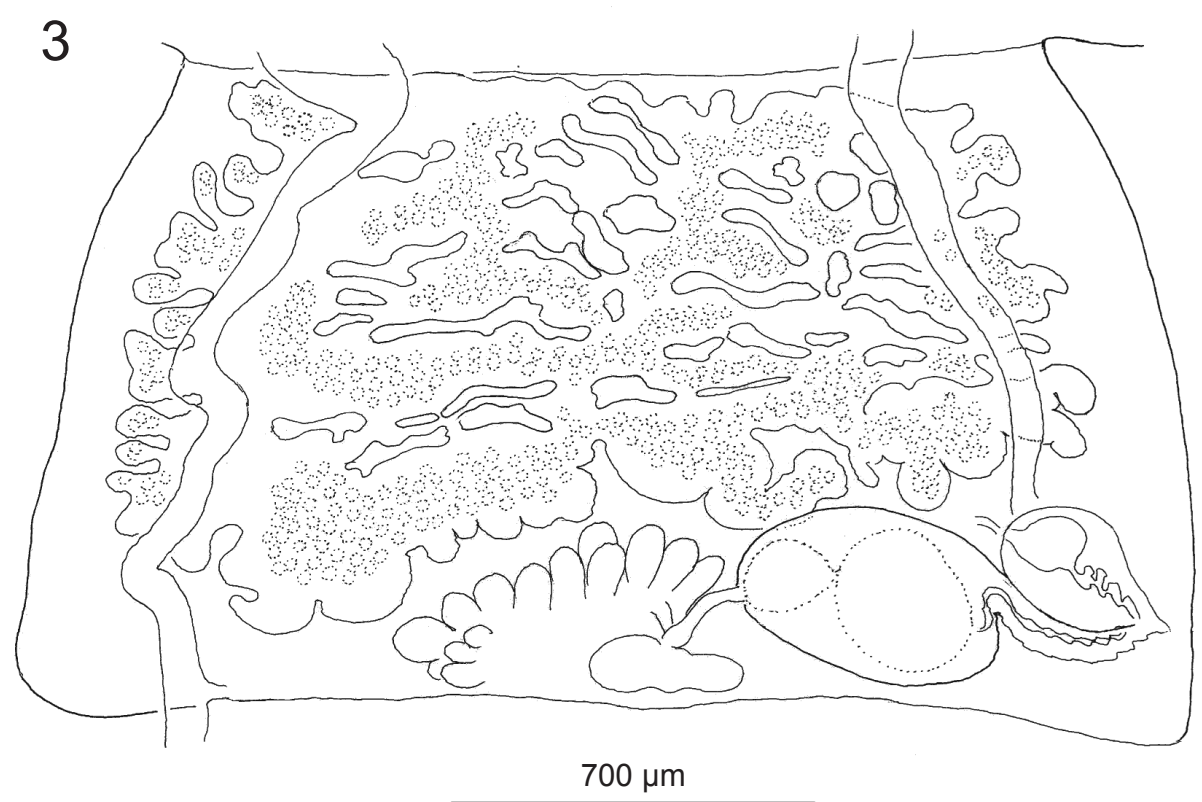

Figs. 1-3. Afrojoyeuxia gundii (Joyeux, 1923) comb. n. from Ctenodactylus gundi. Fig. 1. Scolex and neck (syntype). Fig. 2. Mature proglottid (syntype). Fig. 3. Pregravid proglottid (redrawn from Quentin 1979). Abbreviations: a - cirrus sac; b - vagina.

The ovoid or subspherical shape of the cirrus-sac of A. gundii is unique among Paranoplocephala spp. (s.1.), other species having a distinctly elongated cirrus-sac. Afrojoyeuxia gundii has also a very thick, conical cirrus (when extruded), whereas the cirrus of Paranoplocephala species is slender, usually tapering distally.
Afrojoyeuxia gundii also significantly differs from Paranoplocephala omphalodes and related species representing the monophyletic Paranoplocephala s.s. (see Haukisalmi et al. 2004) in the morphology of the scolex and suckers (see Discussion). 

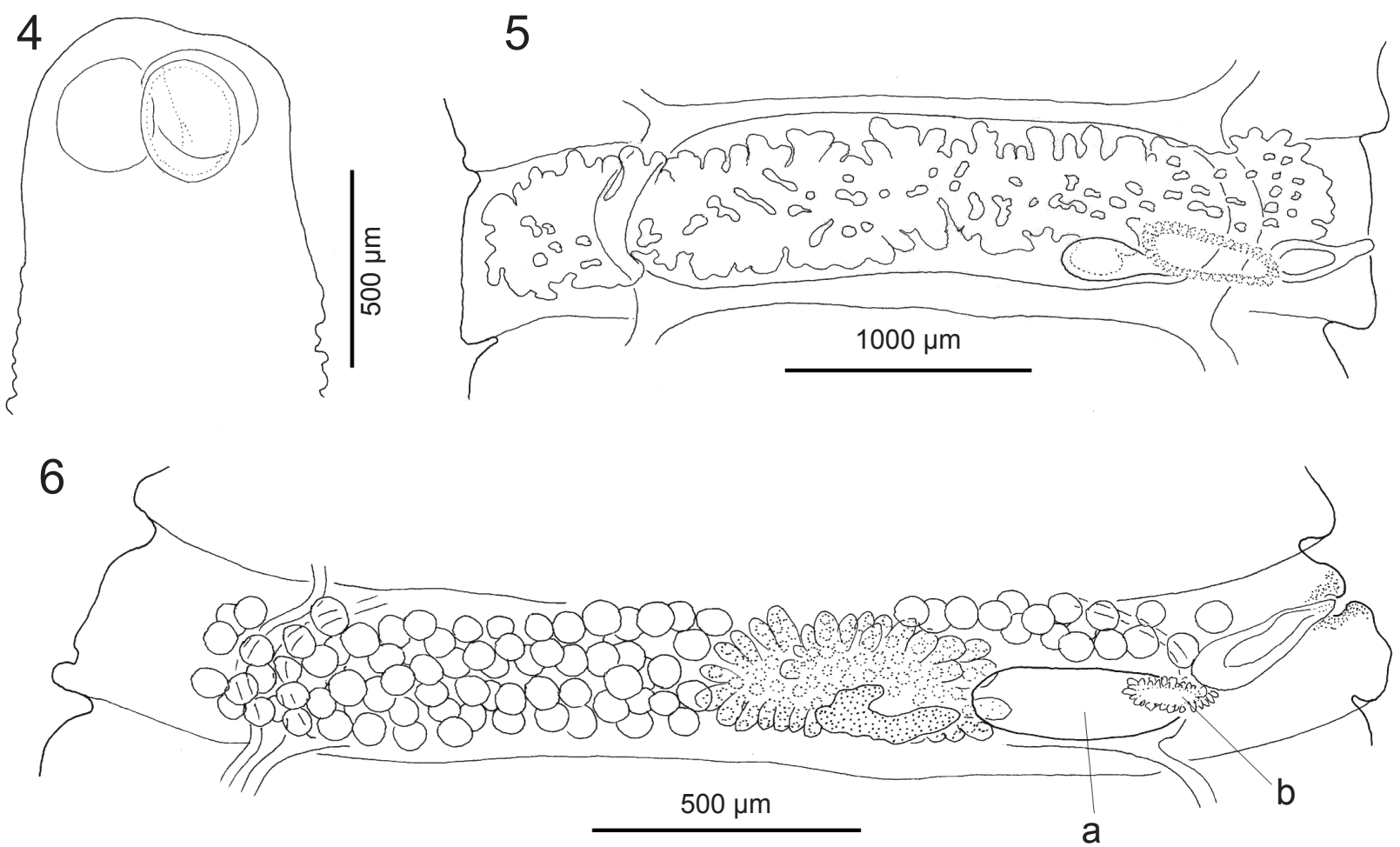

Figs. 4-6. Hunkeleriella dasymidis (Hunkeler, 1972) comb. n. from Dasymys incomtus. Fig. 4. Scolex and neck (paratype). Fig. 5. Pregravid proglottid (holotype). Fig. 6. Mature proglottid (holotype). Abbreviations: a - seminal receptacle; b - external seminal vesicle.

\section{Hunkeleriella gen. $\mathrm{n}$.}

Figs. 4-6

Diagnosis: Strobila short (10-20 mm), but relatively wide (up to $4 \mathrm{~mm}$ ). Scolex prominent, not separate from neck. Neck very short and usually as wide as scolex. Suckers embedded within scolex. Proglottids craspedote, transversely elongated. Genital pores unilateral, exceptionally irregularly alternating, positioned slightly anterior to middle of lateral margin of mature proglottids.

Testes numerous (120-130), mostly antiporal to ovary; smaller group of testes positioned poral to ovary and anterior to genital ducts. Few testes extending across longitudinal osmoregulatory canals on both sides; testes do not overlap ovary. Cirrus-sac elongate, short, barely extending to ventral longitudinal canal. External seminal vesicle prominent, covered with thick layer of glandular cells, expanding markedly in postmature and pregravid segments.

Ovary poral, but not reaching poral ventral canal. Vagina short (about half of cirrus-sac length), narrow, of uniform width, covered with layer of glandular cells, positioned ventral or postero-ventral to cirrus-sac. Seminal receptacle with narrow distal region and elongate, expanded proximal region. Genital ducts pass dorsal to longitudinal osmoregulatory canals. Vitellarium asymmetrically bilobed, slightly poral with respect to ovary.

Uterus initially tube-like, developing into complex sacculated and fenestrated organ in pregravid proglottids, covering most of medulla and extending ventrally across longitudinal ventral canals on both sides. Eggs with pyriform apparatus.

In murid rodents (Dasymys incomtus).

Type and only species: Hunkeleriella dasymidis (Hunkeler, 1972) comb. n. [syns. Andrya dasymidis Hunkeler, 1972; Aprostatandrya dasymidis (Hunkeler, 1972) Hunkeler 1973; Paranoplocephala dasymidis (Hunkeler, 1972) Tenora, Murai et Vaucher, 1984].

Ety mology: The name of the new genus refers to the cestodologist Pierre Hunkeler (Switzerland), the author of $A n$ drya dasymidis.

Remarks. Based on the structure (below), dorsoventral position and transverse extent of the early uterus, the type and only species of Hunkeleriella, H. dasymidis, unambiguously belongs to Paranoplocephala (s.1.). However, $H$. dasymidis is characterized by a very short (10-20 mm) and relatively wide strobila compared with other Paranoplocephala spp. (s.1.). The shortest species within the latter group ( $P$. janickii Tenora, Murai et Vaucher, 1985) is on average $50 \mathrm{~mm}$ long (see Tenora et al. 1985) and most of the other species exceed $100 \mathrm{~mm}$.

The neck of $H$. dasymidis is very short and wide, usually as wide as the scolex, although the anterior region of the holotype specimen is contracted. Within Paranoplocephala (s.1.), most species have a long and slender neck $(<<50 \%$ of scolex width), with a group of species having a wider neck ( $60-80 \%$ of the scolex width), 
namely P. blanchardi (Moniez, 1891) sensu Tenora et al. (1985), P. etholeni Haukisalmi, Henttonen, Niemimaa et Rausch, 2002, P. feodorovi Gulyaev et Chechulin, 1996, P. oeconomi Gubányi et Murai, 2002, and P. yoccozi Haukisalmi et Henttonen, 2005 (Haukisalmi et al. 2002). However, $H$. dasymidis differs from the latter species in the position of the genital pores (see below) and distribution of the testes (in $H$. dasymidis the testes are poral and antiporal to the ovary, whereas in the other 'wide-necked' species there are no testes poral to the ovary).

The genital pores of $H$. dasymidis are unilateral (exceptionally with a few changes per strobila), in which it differs from the species of Paranoplocephala sensu stricto (s.s.) and most of the species within Paranoplocephala s.1., which have irregularly alternating genital pores. In addition, the genital pores of $H$. dasymidis are usually positioned slightly anterior to the middle of proglottid margin in mature proglottids. In most of the Paranoplocephala species (s.1.), the genital pores are positioned posterior to the middle of mature proglottid margin (rarely in the middle of the margin) and never anterior to the middle of the margin.

This may seem as a minor difference, but morphological and molecular data within the 'arvicoline clade' of cestodes (Wickström et al. 2005) suggest that this feature may be phylogenetically and systematically informative. In Paranoplocephala, Microcephaloides Haukisalmi, Hardman, Hardman, Rausch et Henttonen, 2008 and Diandrya Darrah, 1930, the genital pores are usually (slightly) posterior to the middle of proglottid margin (rarely median), whereas the pores of Anoplocephaloides are slightly, but consistently anterior to the middle of margin (Haukisalmi 2009).

Tenora et al. (1986) suggested that $P$. dasymidis can be separated from other species of Paranoplocephala by its unique distribution of testes (without further specifying the feature). The testes of $H$. dasymidis are widely distributed, extending across the longitudinal canals on both sides, with a tendency to form two separate fields. This feature is rare in species of Paranoplocephala (s.1.), but a similar distribution is seen in P. sciuri (Rausch, 1947), P. aquatica Genov, Vasileva et Georgiev, 1996 and P. freemani Haukisalmi, Henttonen et Hardman, 2006.

Of these, $P$. aquatica and $P$. freemani also have a tendency for the testes to occur in two separate groups. Moreover, $P$. freemani has a short vagina and a distally narrow seminal receptacle, features that also characterize $H$. dasymidis. However, these three species of Paranoplocephala differ markedly from $H$. dasymidis in having a much longer and more slender strobila and neck, more posteriorly positioned genital pores and, perhaps, a different type of early uterus.

The layer of glandular cells surrounding the external seminal vesicle is prominent in $H$. dasymidis, which aids in its distinction from most of the species of Paranoplocephala (s.1.).
The structure of early uterus in $H$. dasymidis was not clearly visible in the specimens studied, but Quentin (1979) stated that the uterus first has the form of a transverse tube, which then becomes lobed and reticulated and extends significantly across the osmoregulatory canals. If the early uterus is initially tubiform, that would separate H. dasymidis from Paranoplocephala (s.1.), which always have an initially reticulated early uterus, although the median part may appear cordiform, especially in Paranoplocephala s.s.

In addition to the features discussed above, Hunkeleriella differs unambiguously from Paranoplocephala s.s. in the morphology of the scolex, suckers and neck. The species of Paranoplocephala s.s. have a large scolex with prominent, crateriform suckers directed anteriorly (Haukisalmi et al. 2004), whereas $H$. dasymidis has a relatively small scolex with rather inconspicuos suckers that are more or less embedded within scolex and directed laterally/anterolaterally.

Hunkeleriella shows affinity with Anoplocephaloides s.s., since species of both genera have a short, wide strobila, unilateral genital pores that are positioned anterior to the middle of proglottid margin and an initially tubular uterus. However, H. dasymidis differs conspicuously from Anoplocephaloides due to the pronouned differences in the size and morphology of the scolex (larger and distinctly separate from the neck in Anoplocephaloides), length/width ratio of proglottids (lower in Anoplocephaloides) and structure of the fully developed (pregravid) uterus (saccate, not reticulated in Anoplocephaloides).

\section{DISCUSSION}

Although the molecular phylogenetic resolution of the 'arvicoline clade' of cestodes (see Introduction) is low (Wickström et al. 2005), there is evidence suggesting that Paranoplocephala s.l. is a non-monophyletic assemblage. Specifically, the combined use of two independent molecular markers (cox1, 28S rDNA) showed that Paranoplocephala oeconomi Gubányi et Murai, 2002 and Paranoplocephala nordenskioeldi Haukisalmi, Wickström, Hantula et Henttonen, 2001 are more closely related to Microcephaloides spp. and Diandrya composita Darrah, 1930, respectively, than they are to other species of Paranoplocephala (Wickström et al. 2005, Haukisalmi et al. 2009). More comprehensive data based on sequences of two mitochondrial genes ( $\operatorname{cox} 1$, nadl) corroborate these relationships and suggest additional relationships supporting the non-monophyly of Paranoplocephala s.l. (V. Haukisalmi, L.M. Hardman, E.P. Hoberg, H. Henttonen - unpublished data).

Paranoplocephala s.s. forms a monophyletic, morphologically well-defined assemblage of species within the genus Paranoplocephala (s.1.) (Haukisalmi et al. 2004, Wickström et al. 2005). The type species Paranoplocephala omphalodes and related species are characterized 
by a large scolex with protruding, crateriform suckers directed anteriorly. In other species within Paranoplocephala (s.1.), the scolex is smaller, the suckers are less prominent, more or less embedded within scolex and directed laterally or anterolaterally.

Considering the above facts and the high morphological variability among Paranoplocephala spp. (s.1.), a taxonomic revision is clearly needed for this diverse assemblage. Attempts to reorganize the genus Paranoplocephala (s.1.) have been few. As mentioned above, the proposal of Aprostatandrya for a set of species earlier assigned to Paranoplocephala and Andrya (see Kirshenblat 1938, Spasskii 1951) is refuted by molecular and morphological evidence (Haukisalmi and Henttonen 2003, Haukisalmi et al. 2004).

Since then, a single new genus has been proposed for Paranoplocephala-like species, i.e. Parandrya Gulyaev et Chechulin, 1996 for $P$. feodorovi, but the genus was synonymized with Paranoplocephala by Haukisalmi and Henttonen (2000). However, a subsequent molecular phylogenetic analysis of Haukisalmi et al. (2009b) showed that, contrary to the suggestion of Haukisalmi and Henttonen (2000), P. feodorovi does not belong within Paranoplocephala s.s, and Parandrya should therefore be considered a valid, independent genus.

Although there are no molecular data for Afrojoyeuxia or Hunkeleriella, their approximate phylogenetic position may be predicted from certain morphological features. There are two suggested synapomorphies for species in the 'arvicoline clade' of anoplocephalid cestodes (including Paranoplocephala s.l., Anoplocephaloides, Microcephaloides, Parandrya and Diandrya), i.e. a slightly developed genital atrium (incapable of forming a genital papilla) and an anterior (or anterior and median) early uterus (tubular or reticulate) that extends across the ventral longitudinal canals ventrally (Haukisalmi 2009).

Both of these features characterize Afrojoyeuxia and Hunkeleriella, and it may thus be predicted that they are positioned within the arvicoline clade, the crown clade of mammalian anoplocephaline cestodes. In addition, $A$. gundii and $H$. dasymidis are both characterized by the presence of testes lateral to the ventral longitudinal canals, a feature that occurs in many species in the arvicoline clade of cestodes (particularly in Paranoplocephala s.l. and Microcephaloides), but is very rare in other anoplocephaline cestodes (Spasskii 1951, Beveridge 1994, Haukisalmi 2009).

If $A$. gundii and $H$. dasymidis are truly positioned within the arvicoline clade of cestodes, they would be first species in this clade known to occur in regions where there are practically no arvicoline rodents (voles and lemmings). This would be unexpected, since it appears that this cestode clade has primarily radiated in arvicoline rodents in the Holarctic region and secondarily colonized other rodents (Wickström et al. 2005).

However, it is possible that arvicoline rodents and endemic African rodents have had historically overlapping distributions in northern Africa, providing possibilities for host shifts, although there are evidently no records of (sub)fossils of arvicoline rodents in that region (Repenning et al. 1990). At present, there is a small, isolated population of Microtus guentheri (Danford et Alston) in northern Libya (Amr et al. 2008), which may overlap with Ctenodactylus gundi, the host of $A$. gundii.

Alternatively, the arvicoline clade of cestodes has its origin in African rodents, but the main radiation has taken place later in arvicoline rodents in the Holarctic region. The latter scenario would imply historical range shifts of hosts and subsequent colonization of arvicoline rodents by cestodes of murid rodents. To test this scenario, molecular phylogenetic data would be needed for Afrojoyeuxia, Hunkeleriella and other anoplocephaline cestodes parasitizing murid rodents in Africa (Afrobaeria Haukisalmi, 2008) and elsewhere (Gallegoides Tenora et Mas-Coma, 1978 and Hokkaidocephala Tenora, Gulyaev et Kamiya, 1999).

Acknowledgements. The examination of type materials was accomplished during a visit at the Natural History Museum of Geneva. The help and hospitality of Jean Mariaux and Alain de Chambrier is acknowledged. The author has been supported by NSF PBI award Nos. 0818696 and 0818823.

\section{REFERENCES}

Amr Z., Shenbrot G., Hutterer R., Amori G., Kryštufek B., Yigit N., Mitsain G., Palomo L.J. 2008: Microtus guentheri. IUCN 2012. The IUCN Red List of Threatened Species. Version 2012.2, www.iucnredlist.org/details/23179, 6/2013.

Beveridge I. 1994: Family Anoplocephalidae Cholodkovsky, 1902. In: L.F. Khalil, A. Jones and R.A. Bray (Eds.), Keys to the Cestode Parasites of Vertebrates, Commonwealth Agricultural Bureaux International, Wallingford, Oxfordshire, pp. 315-366.

Chechulin A.I., Gulyaev V.D. 1998: [Paranoplocephala longivaginata sp. n. (Cyclophyllidea: Anoplocephalidae) - a new cestode of rodents from East Siberia.] Parazitologiya 32: 352356. (In Russian.)
Douthitт H. 1915: Studies on the cestode family Anoplocephalidae. Illi. Biol. Monogr. 1: 1-96.

Haukisalmi V. 2008: Review of Anoplocephaloides species from African rodents, with the proposal of Afrobaeria n. g. (Cestoda: Anoplocephalidae). Helminthologia 45: 57-63.

Haukisalmi V. 2009: A taxonomic revision of the genus Anoplocephaloides Baer, 1923 sensu Rausch (1976), with the description of four new genera (Cestoda: Anoplocephalidae). Zootaxa 2057: 1-31.

Haukisalmi V., Henttonen H. 2000: Description and morphometric variability of Paranoplocephala serrata $\mathrm{n}$. sp. (Cestoda: Anoplocephalidae) in collared lemmings (Dicrostonyx spp., 
Arvicolinae) from Arctic Siberia and North America. Syst. Parasitol. 45: 219-231.

Haukisalmi V., Henttonen H. 2001: Biogeography of helminth parasitism in Lemmus Link (Arvicolinae), with the description of Paranoplocephala fellmani n. sp. (Cestoda: Anoplocephalidae) from the Norwegian lemming L. lemmus (Linnaeus). Syst. Parasitol. 49: 7-22.

Haukisalmi V., Henttonen H. 2003: What is Paranoplocephala macrocephala (Douthitt, 1915) (Cestoda: Anoplocephalidae)? Syst. Parasitol. 54: 53-69.

Haukisalmi V., Henttonen H. 2007: A taxonomic revision of the Paranoplocephala primordialis (Douthitt) complex (Cestoda: Anoplocephalidae) in voles and squirrels. Zootaxa 1548: 51-68.

Haukisalmi V., Henttonen H., Hardman L.M., Hardman M., Laakkonen J., Murueva G., Niemimaa J., Shulunov S., VaPALAHTI O. 2009: Review of tapeworms of rodents in the Republic of Buryatia, with emphasis on anoplocephalid cestodes. ZooKeys 8: 1-18.

Haukisalmi V., Henttonen H., Niemimaa J., Rausch R.L. 2002: Description of Paranoplocephala etholeni n. sp. (Cestoda: Anoplocephalidae) in the meadow vole Microtus pennsylvanicus, with a synopsis of Paranoplocephala s.l. in Holarctic rodents. Parasite 9: 305-314.

Haukisalmi V., Rausch R.L. 2007: Paranoplocephala sciuri (Rausch, 1947) (Cestoda: Anoplocephalidae), a parasite of the northern flying squirrel (Glaucomys sabrinus), with a discussion of its systematic status. Comp. Parasitol. 74: 1-8.

Haukisalmi V., Wickström L.M. 2005: Morphological characterisation of Andrya Railliet, 1893, Neandrya n. g. and Paranoplocephala Lühe, 1910 (Cestoda: Anoplocephalidae) in rodents and lagomorphs. Syst. Parasitol. 62: 209-219.

Haukisalmi V., Wickström L.M., Hantula J., Henttonen H. 2001: Taxonomy, genetic differentiation and Holarctic biogeography of Paranoplocephala spp. (Cestoda: Anoplocephalidae) in collared lemmings (Dicrostonyx; Arvicolinae). Biol. J. Linn. Soc. 74: 171-196.

Haukisalmi V., Wickström L.M., Henttonen H., Hantula J., Gubányi A. 2004: Molecular and morphological evidence for

Received 3 May 2013 multiple species within Paranoplocephala omphalodes (Cestoda, Anoplocephalidae) in Microtus voles (Arvicolinae). Zool. Scr. 33: 277-290.

Joyeux C. 1923: Recherches sur la faune helminthologique Africaine. Arch. Inst. Pasteur Tunis 12: 119-167.

Kirshenblat Y.D. 1938: [Generalities in the Dynamics of the Parasite Fauna of Mouse-like Rodents.] Izdanie Lenindgradskogo Gosudarstvenogo Universiteta, 92 pp. (In Russian.)

Quentin J.-C. 1979: Anatomie et taxonomie d'Aprostatandrya gundi (Joyeux, 1923), cestode parasite du rongeur Ctenodactylus gundi (Rothman). Bull. Mus. Nat. Hist. Nat. A 1: 251-256.

Rausch R. 1947: Andrya sciuri n. sp., a cestode from the northern flying squirrel. J. Parasitol. 33: 316-318.

Rausch R.L. 1976: The genera Paranoplocephala Lühe, 1910 and Anoplocephaloides Baer, 1923 (Cestoda: Anoplocephalidae), with particular reference to species in rodents. Ann. Parasitol. Hum. Comp. 51: 513-562.

Repenning C.A., Fejfar O., Heinrich W.D. 1990: Arvicolid rodent biochronology of the Northern Hemisphere. In: O. Fejfar and W.D. Heinrich (Eds.), International Symposium on Evolution, Phylogeny, and Biostratigraphy of Arvicolids (Rodentia, Mammalia), Pfeil-Verlag, Prague, pp. 385-418.

SPASSKII A.A. 1951: [Anoplocephalate tapeworms of domestic and wild animals.] The Academy of Sciences of the USSR, Moscow, 783 pp. (In Russian.)

Tenora F., Murai E., Vaucher C. 1984: On Anoplocephalidae (Cestoda), parasitizing Rodentia and Lagomorpha in Europe. Parasitol. Hung. 17: 51-57.

Tenora F., Murai É., Vaucher C. 1985: On some Paranoplocephala species (Cestoda: Anoplocephalidae) parasitizing rodents (Rodentia) in Europe. Parasitol. Hung. 18: 29-48.

Tenora F., Murai É., Vaucher C. 1986: On Andrya Railliet, 1893 and Paranoplocephala Lühe, 1910 (Cestoda, Monieziinae). Parasitol. Hung. 19: 43-75.

Wickström L.M., Haukisalmi V., Varis S., Hantula J., HentTONEN H. 2005: Molecular phylogeny and systematics of anoplocephaline cestodes in rodents and lagomorphs. Syst. Parasitol. 62: 83-99.

Accepted 4 June 2013 